Dominik Mierzejewski

Uniwersytet Łódzki

\title{
W pułapce wspólzależności. Dylematy wyboru narzędzi w amerykańskiej polityce ChRL
}

Relacje chińsko-amerykańskie stają się jednymi z najważniejszych biegunów współczesnych stosunków międzynarodowych. W dobie kryzysu gospodarczego Stanów Zjednoczonych, a także europejskiego kryzysu strefy euro, coraz większą wagę przykłada się do wzrastającego znaczenia Chin. W tym kontekście problemem kluczowym staje się zdefiniowanie celów polityki zagranicznej Chin, następnie ocena zachowania i reakcji Stanów Zjednoczonych oraz $\mathrm{w}$ konsekwencji analiza stosowanych przez władze w Pekinie mechanizmów i narzędzi. Te natomiast, mając różne podłoże, stwarzają różne płaszczyzny oddziaływania. Innym czynnikiem wpływającym na dobór narzędzi stała się implementacja strategii „wyjścia na zewnątrz” i globalizacja interesów Chińskiej Republiki Ludowej. Rzecz jasna stopień ich wykorzystania, z jednej strony, jest wynikiem materialnego potencjału państwa, rozumianego jako „kompleksowa siła państwa”, z drugiej zaś - wynika z kultury strategicznej wieloznaczności, która umożliwia realizowanie uprzednio przedkładanych celów. Istotne jest podkreślenie, iż z uwagi na zmniejszające się różnice potencjałów, relacje wzajemne nabierają nowej dynamiki, a oba podmioty, z racji na decydującą rolę stosunków bilateralnych w kształtowaniu architektury stosunków międzynarodowych, zmuszone są do poszukiwania nowych platform porozumienia i dialogu. Niewątpliwie do głównych narzędzi w amerykańskiej polityce Chin dekady Hu Jintao (2002-2012) należy

1 „Kompleksowa siła państwa” składa się z elementów materialnych i duchowych (niematerialnych), tworząc trzy wymiary: przetrwania, rozwoju i międzynarodowego oddziaływania. Do jej głównych elementów zaliczono: potencjał demograficzny, rozmiar terytorium, zdolność ekonomiczną, np. PKB, zdolności wojskowe, strategię, taktykę prowadzenia walki, zdolności do prowadzenia operacji wojskowych. Por. Li Mingjian, China Debates Soft-Power, „Chinese Journal of International Politics” 2008, vol. 2, s. 287-308 oraz w literaturze polskiej tekst prof. Jana Rowińskiego, Ewolucja polityki zagranicznej ChRL (1949-2011), [w:] Wielkie przemiany w Chinach. Próba bilansu reform Deng Xiaopinga, red. K. Gawlikowski, M. Ławacz, Wydawnictwo SWPS, Warszawa 2012, s. 223-260. 
zaliczyć: próbę stworzenia alternatywnego modelu rozwoju względem Zachodu, określanego w Chinach jako „socjalizm z chińską specyfiką”, coraz szersze oddziaływanie przez sieć Instytutów Konfucjusza, aktywny udział w G20 i próby gospodarczej redefinicji układu międzynarodowego oraz modernizację sił zbrojnych i budowę środków zaufania przez strategiczny bilateralny dialog i próbę stworzenia kompleksu bezpieczeństwa wokół problemu nuklearnego Koreańskiej Republiki Ludowo-Demokratycznej².

\section{Tło historyczne i otoczenie międzynarodowe relacji bilateralnych}

Głębsze zrozumienie oddziaływania Chin na Stany Zjednoczone nie jest możliwe bez znajomości tła historycznego oraz otoczenia międzynarodowego ich dwustronnych stosunków. Począwszy od pierwszych kontaktów w 1784 r., kiedy to amerykański poseł Samuel Shaw przybył do Guangzhou, przez rozpoczęcie działalności gospodarczej w 1803 r. na południu Chin oraz wojny opiumowe (1839-1842, 1856-1860), a także zmiany w amerykańskiej percepcji własnej roli w regionie Azji i Pacyfiku, relacje te nabierały nowego znaczenia $^{3}$. Za sprawą starań dyplomatycznych podejmowanych przez sekretarza stanu Williama Sewarda administracja Abrahama Lincolna coraz uważniej przyglądała się Chinom i Japonii. W kolejnych latach prowadzono politykę otwartych drzwi, stanowiącą przeciwwagę dla działań Wielkiej Brytanii, dążącej do całkowitego uzależnienia Chin, a także fundowano stypendia dla przedstawicieli chińskich elit, którzy studiowali w Stanach Zjednoczonych ${ }^{4}$. Przykładem rosnącego zainteresowania USA regionem Azji Wschodniej była misja zorganizowana przez posła amerykańskiego Ansona Burlingame'a, który od 1867 r. przewodził ponad 30-osobowej chińskiej misji do Stanów Zjednoczonych oraz państw europejskich ${ }^{5}$. Co ważne, z uwagi na swoją koncyliacyjną postawę, był on pierwszym posłem uznanym przez Cesarstwo Chińskie. Następnie repre-

2 Wang Hongtao, Xinshiji Zhong Mei guanxi yanjiu yu Zhong Mei guanxi [Badania stosunków chińsko-amerykańskich w nowym stuleciu i ich relacje dwustronne]), „Xiandai Guoji Guanxi” 2009 , no. 6, s. 58-59.

3 M.H. Hunt, The Making of a Special Relationship: The United States and China to 1914, Columbia University Press, New York 1983, s. 5-7.

4 W.I. Cohen, American's Response to China, An Interpretative History of Sino-America Relations, second edition, John Willeys and Sons, New York, Chickerer, Brisbone, Toronto 1980, s. 30-32 oraz 165-167 oraz D.M. Crane, Th. A. Breslin, An Ordinary Relationship:American Opposition to Republican Revolution in China. Contributors, University Press of Florida, Gainesville 1986, s. 36-60.

5 Szerzej na temat postaci Burlingame'a patrz: D.L. Anderson, Imperialism and Idealism: American Diplomats in China, 1861-1898, Indiana University Press, Bloomington 1986, s. 16-20. 
zentował Chiny jako „specjalny wysłannik cesarski” w państwach europejskich i Stanach Zjednoczonych ${ }^{6}$.

Polityka amerykańska odegrała również istotną rolę w niwelowaniu niekorzystnego dla Chin konfliktu mocarstw na ich terenie. W 1899 r. sekretarz stanu John Hay postulował, by poszczególne mocarstwa nie naruszały w swoich strefach wpływów interesów innych państw, domagał się wprowadzenia jednolitych stawek celnych i zniesienia dyskryminacji handlowej wobec innych podmiotów ${ }^{7}$. W wyniku takiej polityki idee amerykańskiego republikanizmu stawały się w Chinach coraz żywsze. Bazowano na nich przy tworzeniu chińskiego systemu republikańskiego, który miał stanowić o nowym modelu politycznym po obaleniu cesarstwa w 1911 r. ${ }^{8}$ Mimo tego dyplomacja amerykańska zdecydowanie opowiadała się za reformowaniem monarchii, nie zaś za jej obaleniem i stworzeniem nowego ustroju. Z punktu widzenia relacji dwustronnych w 20-leciu międzywojennym ważne było stanowisko dyplomacji amerykańskiej w czasie konferencji w Waszyngtonie z 1922 r., na której ostatecznie przywrócono Chinom prawa do prowincji Shandong 9 , oraz uznanie przez USA rządu narodowego Chang Kai-sheka za reprezentanta Chin po rozpadzie zjednoczonego frontu w 1927 r. ${ }^{10}$

Po II wojnie światowej, w obliczu nieuchronnego konfliktu między Partią Narodową a Komunistyczną Partią Chin, Stany Zjednoczone próbowały doprowadzić do porozumienia. Jednak negocjacje z sierpnia 1945 r. w Chongqingu dały jedynie połowiczny sukces, a obie strony czyniły przygotowania do wojny domowej. Po przegranej Partii Narodowej stało się jasne, że relacje między KPCh a amerykańskimi administracjami nie będą należały do najprostszych ${ }^{11}$. Jednak mimo wojny koreańskiej i prowadzonych operacji amerykańskich w Wietnamie udało się nawiązać kontakty i normalizować relacje wzajemne, czego najlepszym przykładem były rozmowy prowadzone w Warszawie (1958-1970). W układzie zimnowojennym wspólnym punktem odniesienia była polityka wobec Związku Radzieckiego, a równoważenie potencjałów stawało się kluczowym elementem $\mathrm{W}$ polityce międzynarodowej. W ramach przygotowań do nawiązania relacji

${ }^{6}$ Zhang Buxian, Cong Zongli Yamen dao Waijiaobu - jianlun wan Qing jindaihua [Od Zongli yamen do ministerstwa spraw zagranicznych - dyskusja o modernizacji w okresie późnej dynastii Qing], „Shandong Shifan Daxue Bao” 1997, no. 3, s. 68-69.

7 M.H. Hunt, op. cit., s. 188-190 oraz J. Israel, Progressivism and the Open Door: America and China, 1905-1921, University of Pittsburgh Press, Pittsburgh 1971, s. 100-105.

8 Por. m.in. J. Pajor, Stanowisko USA wobec Chin podczas powstanie Yihetuan, „Azja Pacyfik” 2012, nr 14, s. 183-210 oraz R. Payne, St. Chen, Sun Yat-Sen: A Portrait, John Day, New York 1946, s. $101-103$.

9 J. Polit, Mocarstwa wobec Rewolucji Xinhai, „Azja Pacyfik” 2012, nr 14, s. 87-106.

${ }_{10}$ Chronology of US-China Relations 1784-2000, [ strona internetowa Departamentu Stanu USA] http://history.state.gov/countries/issues/china-us-relations [dostęp 11.01.2012].

11 Por. S. Pawlak, Polityka Stanów Zjednoczonych wobec Chin 1941-1955, Wydawnictwo PWN, Warszawa 1973, s. 110-120. 
najważniejszym wydarzeniem była wizyta Richarda Nixona w Chinach (luty 1972 r.) i podpisanie tzw. komunikatu szanghajskiego, który określał ramy stosunków bilateralnych ${ }^{12}$. W wyniku zmian zachodzących $\mathrm{w}$ Chinach przełom w stosunkach dwustronnych stanowiło nawiązanie kontaktów dyplomatycznych w 1979 r. Przyjęcie polityki reform i otwarcia (gaige kaifang) oznaczało powolne wychodzenie z izolacjonizmu okresu maoistowskiego i otwarcie na państwa zachodnie. W latach 80., z uwagi na amerykańską politykę wobec ZSRR, współpraca chińsko-amerykańska układała się pomyślnie ${ }^{13}$. Pod koniec tego dziesięciolecia, wraz z powolnym demontażem systemu komunistycznego w państwach Europy Środkowej i de facto upadku Związku Radzieckiego, wymiar geopolityczny owych relacji stopniowo tracił na znaczeniu. Ameryka, po wydarzeniach na placu Tian'anmen w czerwcu 1989 r., nieoficjalnie nawiązała kontakty z władzami w Chinach, jednak amerykański Kongres domagał się zdecydowanej reakcji. Taka polityka interpretowana była w Pekinie jako próba narzucenia amerykańskiego modelu ustrojowego Chinom i rozpoczęcie kolejnej rozgrywki, opartej na zasadach zimnowojennej rywalizacji. Zaproponowana przez Deng Xiaopinga zasada taoguang yanghui - ukrywania własnych możliwości ${ }^{14}$ - umożliwiła Chinom przetrwanie w niesprzyjających okolicznościach i prowadzenie reform niezbędnych dla wzmocnienia gospodarczego państwa. W takiej sytuacji stosunki z Waszyngtonem zostały ograniczone, ale nie zerwane. Oba państwa, za sprawą misji Brenta Scowcrafta w 1989 r., a następnie spotkań Richarda Nixona, utrzymywały kontakty nieformalne ${ }^{15}$. Wspomniane nawiązanie kontaktów nie oznaczało powrotu do stanu relacji z lat 80 . Jak powszechnie oceniano, Chiny miały być ,strategicznym rywalem" Stanów Zjednoczonych. W taki sposób administracja Busha postrzegała Pekin, a dążąc do zacieśnienia relacji z Japonią i Koreą Południową próbowano ograniczać wpływy chińskiej dyplomacji ${ }^{16}$.

Do zmiany amerykańskiej percepcji Chin przyczyniły się wydarzenia z 11 września 2001 r. Atak terrorystyczny na Nowy Jork i Waszyngton wskazywał, że amerykańska walka na dwa fronty - zarówno przeciwko terroryzmowi,

${ }^{12}$ H. Kissinger, Dyplomacja, Philip Wilson, Warszawa 2001, s. 773-802.

13 Por. wypowiedź Zbigniewa Brzezińskiego w czasie spotkania na Forum Młodych Dyplomatów 16 maja 2009 r., [kanał Fundacji im. Kazimierza Pułaskiego na portalu YouTube] , http:// www.youtube.com/playlist?list=PLCCB6CB169446212A [dostęp 11.12.2012].

${ }_{14}$ Taoguang yanghui w literaturze chińskiej występowało również jako taoguang huiji, interpretowane jako ukrywanie własnych możliwości, z naciskiem na skrywanie własnych śladów, taoguang mieji podobnie - z naciskiem na zacieranie śladów czy taoguang yinji - z naciskiem na ukrywanie śladów. Por. hasło przedmiotowe taoguang yanghui [w] Jingbian Chengyu Cidian [Słownik idiomów], Shanghai Cishu Chuban she, Shanghai 1993, s. 741.

15 Szerzej na ten temat patrz: G. Bush, B. Scowcraft, Świat przekształcony, Świat Książki, Warszawa 2000, s. 115-120.

${ }^{16}$ H. Harding, Asia in American Grand Strategy: The Quadrennial Defense Review and the National Security Strategy, [w:] George W. Bush and Asia. A Midterm Assesment, ed. by R.M. Hathaway, W. Lee, Woodrow Wilson Centre for Scholars, Washington 2002, s. 43-50. 
jak i Chińskiej Republice Ludowej - nie była możliwa. W tej sytuacji głównym zadaniem amerykańskiej dyplomacji było jak najszersze włączenie Chin do globalnej koalicji antyterrorystycznej. Mimo początkowego poparcia dla amerykańskich działań, z czasem strona chińska zaczęła dostrzegać zagrożenia, jakie niosło za sobą wzmocnienie amerykańskiej pozycji w regionie Azji. Przede wszystkim zwiększenie pomocy dla państw graniczących z Chinami, m.in. Japonii, Filipin czy państw Azji Środkowej, kreowało wrażenie otaczania Państwa Środka. Poprzez pomoc wojskową dla państw-sąsiadów Chin Waszyngton ograniczał swobodę w kształtowaniu chińskiej polityki i utrudniał jej prowadzenie, a tym samym starał się wyeliminować niektóre narzędzia dyplomacji wielostronnej forowane przez Pekin ${ }^{17}$. Z drugiej strony, amerykańska wojna z terroryzmem została wykorzystana przez władze w Pekinie jako pretekst do rozwiązywania własnych problemów wewnętrznych z separatyzmem, m.in. w Xinjiangu. Pod presją niechętnie nastawionej opinii publicznej oraz własnych kalkulacji strona chińska nie dołączyła do międzynarodowych sił wojskowych interweniujących w Afganistanie. Amerykańskie wojny postrzegane były w Pekinie jako część konfrontacji ideologicznej wartości amerykańskich z islamskim radykalizmem. Taka percepcja wskazywała, że największe napięcia w relacjach chińsko-amerykańskich będą istniały na polu systemów wartości ${ }^{18}$.

Nowa sytuacja geopolityczna wymuszała poszukiwanie nowej formuły, do której zaliczono stworzenie podstaw dla „,szczerych, konstruktywnych i opartych na współpracy" relacji bilateralnych. Określenie relacji jako niepozorowanych i szczerych stanowiło dla strony chińskiej dodatkowe wyzwanie, związane z odejściem od strategicznej kultury chińskiej, która preferowała ukrywanie własnego potencjału i celów. Ważna była również akcesja Chin do Światowej Organizacji Handlu, która umożliwiła im większą ekspansję na rynkach światowych, stanowiąc tym samym większe wyzwanie dla polityki Waszyngtonu ${ }^{19}$.

We wrześniu 2005 r., w odpowiedzi na argumentację strony chińskiej o „pokojowym wzrastaniu” Chin, Robert Zoellick nazwał je „odpowiedzialnym mocarstwem”. Podobny wydźwięk miała wypowiedź George’a Busha z marca 2006 r., który nie określał Chin mianem państwa „totalitarnego” czy „niedemokratycznego", lecz państwa, które obrało własną drogę rozwoju ${ }^{20}$. Taka sytuacja, zdaniem chińskich elit, miała prowadzić do stworzenia systemu międzynarodowego

${ }_{17}$ Zhang Xizheng, Zhongguo zai Dongnan Ya de ruanshi li yu Zhong Mei guanxi [Chińskie soft-power w Azji Południowo-Wschodniej i stosunki chińsko-amerykańskie], „Nanya Wenti Yanjiu" 2009, no. 4, s. 8-9.

${ }_{18}$ Gao Zugui, What Strategic Outlook Holds for America in Iraq?, „Contemporary International Relations” 2006, no. 3, s. 19; o konflikcie ideologicznym patrz R. Bernstein, R. Munro, The Cominig Conflict with America, „Foreign Affairs” 1997, no. 2, s. 18-32.

19 Jianwei Wang, Building the New Conceptual Framework for U.S.-China Relationship, [w:] Challenges to Chinese Foreign Policy, ed. by Yufan Hao, C.X. George Wei, L. Dittmer, The University Press of Kentucky, Lextington 2009, s. 41-42.

20 Ibidem, s. 47-49. 
opartego na zasadach corporate governance, w którym Chiny powinny wykorzystać swoją strategiczną szansę ${ }^{21}$.

Zmiana stanowiska administracji W. Busha, wynikająca ze zmian w środowisku międzynarodowym i konfliktu asymetrycznego $\mathrm{z}$ terroryzmem oraz wzrastającego potencjału gospodarczego Chin, nieuchronnie prowadziła do rozpoczęcia nowego wymiaru stosunków dwustronnych, które z czasem określone zostały przez stronę chińską jako „relacje między mocarstwami nowego typu”"22. Wykorzystując zaangażowanie amerykańskie, dyplomacja chińska zaczęła aktywnie promować działania na rzecz tworzenia multilateralnych struktur, przede wszystkim Szanghajskiej Organizacji Współpracy, mającej na celu równoważenie amerykańskiej obecności w regionie Azji. Od 2006 r. Chiny i Stany Zjednoczone rozpoczęły rozmowy w ramach Strategicznego i Gospodarczego Dialogu (Strategic and Economic Dialogue) oraz Dialogu na Wysokim Szczeblu (Senior Dialogue), który z czasem stał się podstawowym wymiarem kontaktów bilateralnych. Stany Zjednoczone dążyły do stworzenia mechanizmu dwustronnego, odpowiedzialnego za zarządzanie sprawami globalnymi G2. Jednak, jak się okazało, strona chińska nie zaakceptowała amerykańskiej propozycji, rozpoczynając aktywnie promocję współpracy w ramach multilateralnej formuły G20. Chiny obawiały się bowiem, że stworzenie bilateralnego mechanizmu z czasem nie będzie korzystne, a Amerykanie będą starali się wciągnąć Pekin do gry, by powtórzyć scenariusz upadku Związku Radzieckiego. W odpowiedzi Amerykanie ogłosili pivot to Asia, uznając, iż region Azji i Pacyfiku będzie stanowił podstawowy element amerykańskiej polityki zagranicznej ${ }^{23}$.

\section{Chińskie oceny amerykańskiej polityki}

Z perspektywy relacji bilateralnych najistotniejszym punktem odniesienia w prowadzonej polityce zagranicznej Chińskiej Republiki Ludowej stały się Stany Zjednoczone. W ramach analizy stosowanych narzędzi istotną kwestią jest przedstawienie oceny prowadzonej przez Stany Zjednoczone polityki względem Chin. Ta określana jest, jak wskazuje perspektywa realistyczna, na bazie materialnego potencjału państwa ${ }^{24}$.

${ }_{21}$ Wang Jun, Zhongguo daxiang haishi qingwa? [Chiny: słoń czy żaba?], http://www.tecn.cn/ data/detail.php?id=10493 [dostęp 8.09.2008].

22 Chin. xinxing daguo guanxi [新型大国关系]. Taka formuła ma odpowiadać nowym wyzwaniom, przed jakimi stoją globalne stosunki międzynarodowej, do których zalicza się wyjście ze światowej recesji czy walkę z globalnym ociepleniem.

23 R. Cossa, B. Glosserman, Regional Overview: They're Back!, „Comparative Connections. A Quarterly E-Journal on East Asian Bilateral Relations” 2010, vol. 11, no. 4, http://csis.org/files/ publication/0904qoverview.pdf [dostęp 11.12.2013].

${ }^{24}$ L. Freedman, China as a Global Strategic Power, [w:] Does China Matter? Essays in Memory of Gerald Segal, ed. by B. Buzan, R. Foot, Routledge, London-New York 2005, s. 21-31. 
Jak trafnie zauważył Jin Canrong, amerykanista z Uniwersytetu Ludowego w Pekinie, dla określenia celów należy przede wszystkim przedstawić problemy w relacjach bilateralnych. Do takich zaliczył trzy grupy: 1) problemy dotyczące chińskiej suwerenności: Tajwan, Tybet, Xinjiang, Morze Południowochińskie; 2) kwestia praw człowieka; 3) sprawy bieżące - podobne jak w relacjach z innymi podmiotami: sprawy handlowe, ochrona środowiska ${ }^{25}$. Zdaniem Su Hao, z pekińskiego Instytutu Dyplomatycznego, relacje chińsko-amerykańskie po zimnej wojnie opierały się na czterech głównych wymiarach: ideologicznym, strategicznym, handlowym i tajwańskim. Wydarzenia z czerwca 1989 r. na placu Tian'anmen umożliwiły Waszyngtonowi próbę narzucenia idei wolności i demokracji jako główną w relacjach bilateralnych. Takie narzędzie miało wzmacniać dominację w stosunkach dwustronnych i ochronę własnych interesów. Kwestie bezpieczeństwa, takie jak embarga na dostawy broni do Chin, rozbrojenie, sprawy broni masowego rażenia oraz kwestii handlowych i problemu Tajwanu, pozostawały istotne, choć w dalszym ciągu sprzeczności ideologiczne w relacjach bilateralnych były uznawane za podstawowe ${ }^{26}$. Wątek tajwański w zakresie sprzedaży broni, budowy środków zaufania w relacjach wojskowych w Cieśninie Tajwańskiej oraz międzynarodowej aktywności Tajwanu stanowił papierek lakmusowy stosunków chińsko-amerykańskich ${ }^{27}$.

W chińskich ocenach relacji bilateralnych dość powszechnie panuje przekonanie, że Stany Zjednoczone próbowały powtórzyć wariant z końca lat 40. w polityce radzieckiej. Otaczanie i powolna izolacja miały stać się kontynuacją „zimnowojennego myślenia” w polityce Waszyngtonu. Amerykańska administracja prowadziła politykę wykluczania Chin, rozumianą w trzech aspektach: 1) kontrola Chin przez próbę wpływania na problem Tajwanu oraz Tybetu; 2) lansowanie teorii zagrożenia chińskiego, promowanie antychińskich nastrojów wśród azjatyckich sąsiadów Chin; 3) kontrola w strukturach Organizacji Narodów Zjednoczonych, wywieranie presji na problem praw człowieka w Chinach ${ }^{28}$. W zależności od potrzeb politycznych, jak stwierdza Jin Canrong, w relacjach

25 Jin Canrong, A Responce to Ted Osius: Policy Legacy and Political Context in U.S. Relations with China, „Asia Affairs: An American Review” 2001, no. 3, s. 134-137.

$26 \mathrm{Su}$ Hao, Zhong Mei guanxi zonglun [Ogólnie o stosunkach Chiny-USA], „Waijiao Xueyuan Xuebao" 1996, nr 2, s. 16-26; W. Bert, The United States, China and Southeast Asia, A Changing of the Guard?, Palgrave, Macmillan, New York 2003, s. 60 oraz Zhao Pingan, Li Xuebao, Guo Yuan, Lengzhan hou Meiguo dui Hua zhengce de tiaozhen yu Zhong Mei guanxi de zouxiang [Dostosowanie amerykańskiej polityki wobec Chin po zimnej wojnie oraz kierunki relacji bilateralnych], „Waijiao Xueyuan Xuebao” 1996, no. 3, s. 14-18.

27 Wang Jisi, Zhong Mei guanxi de fazhanqushi yu shencun yuanyin [Podstawy i tendencje w stosunkach chińsko-amerykańskich], „Dang dai Ya-tai” 2009, no. 3, s. 10-11.

28 Jin Canrong, Liu Shiqiang, Aobama zhizheng yi lai de Zhong Mei guanxi [Stosunki chińsko-amerykańskie pod rządami Obamy], „Meiguo Yanjiu” 2009, no. 4, s. 30-41 oraz Li Shouyuan, „Lengzhan siwei” yu lengzhan hou Meiguo de dui Hua zhengce [Myślenie zimnowojenne oraz amerykańska polityka wobec Chin], „Waijiao Xueyuan Xuebao” 1996, no. 3, s. 21-22. 
bilateralnych prawa człowieka zyskiwały na znaczeniu bądź były marginalizowane. W tym kontekście polityka amerykańska postrzegana była jako dwulicowa z kilku względów. Waszyngton np. mówił o prawach człowieka w innych krajach, nie oceniając własnych standardów, dyskurs w zakresie wolności był tylko narzędziem w polityce zdobywania dominacji na świecie i wywierania presji w celu osiągnięcia korzyści politycznych ${ }^{29}$.

W podobnym tonie oceniano oczekiwania amerykańskie co do „odpowiedzialnego mocarstwa". Z perspektywy chińskiej Amerykanie prowadzili grę, która miała na celu skłonienie Pekinu do współrządzenia globalnym systemem stosunków międzynarodowych. Oczekiwania „odpowiedzialnego mocarstwa” wpisywały się w amerykańską politykę wywierania presji na Chiny, podobnie jak w przypadku lansowanej teorii ,zagrożenia chińskiego" w latach 90. XX w. Należy jednak zwrócić uwagę, że nie były to oczekiwania bezpodstawne. O ile w $1991 \mathrm{r}$. udział amerykańskiego PKB w światowej gospodarce stanowił 25,99\%, a chińskiego 1,83\%, to w 2008 r. proporcje te wynosily odpowiednio $23,44 \%$ oraz $7,23 \%{ }^{30}$.

Dodatkowym elementem stała się amerykańska polityka w regionie Azji Wschodniej i Południowej. W tym kontekście na pierwszy plan wysuwa się polityka Waszyngtonu wobec Japonii, Indii i państw Azji Południowo-Wschodniej. Stany Zjednoczone uznawały udział państw trzecich w relacjach bilateralnych za bardzo istotny. W zależności od sytuacji międzynarodowej alianci amerykańscy, np. Japonia, w sporze z Chinami mogli liczyć na pomoc amerykańską ${ }^{31}$. Tak było w lutym i październiku 2005 r., kiedy przyjęto dokument Transformation and Realingments for the Future, który miał wskazywać przyszłość współpracy wojskowej. W konsekwencji w maju $2006 \mathrm{r}$. między Bushem a premierem japońskim Koizumim podpisano porozumienie Japan-U.S. Alliance of the New Century. $\mathrm{W}$ polityce prowadzonej wobec Indii Stany Zjednoczone gwarantowały pomoc w modernizacji hinduskich sił zbrojnych, organizując m.in. wspólne ćwiczenia, a także wspierając program nuklearny Indii ${ }^{32}$. Jak stwierdza Bernard Gordon: „Podstawą polityki amerykańskiej od czasów Theodore'a Roosevelta jest sprzeciw wobec dominacji jednego państwa w jakimkolwiek regionie świata"33. Z tego punktu widzenia państwa regionu Azji Wschodniej i Południowo-Wschodniej postrzegają Waszyngton jako gwaranta stabilizacji i bezpieczeństwa w regionie ${ }^{34}$.

${ }^{29}$ Liu Wenzong, Baquanzhuyi de zhuolie biaoxian [Niezdarne manifestacje hegemonizmu], „Waijiao Xueyuan Xuebao” 1995, no. 2, s. 47-49.

30 Liang mian xing: Meiguo dui Hua zhengce de zhangqi zhanlue [Podwójny wymiar: długoterminowa strategia polityki amerykańskiej wobec Chin], http://www.qstheory.cn/ hqwg/2010/201007/201004/t20100413_26627.htm [dostęp 12.12.2012].

31 Jin Canrong, Liu Shiqiang, op. cit., s. 44.

32 S. Mahmud Ali, U.S.-China Relations in the "Asia Pacific” Century, Palgrave, Macmillan, New York 2008, s. 173-175.

33 Cyt. za W. Bert, op. cit., s. 25-26.

34 Ibidem, s. 23. 
W tym kontekście stanowi to istotne wyzwanie dla polityki Chin i stosowanych w ich polityce zagranicznej narzędzi. Mimo że, jak zauważa David Shambaugh, zarówno USA, jak i Chiny nie mają potencjału do bycia strategicznymi rywalami, to jednak Stany Zjednoczone postrzegają Chiny jako podmiot próbujący zdominować scenę regionalną, a następnie globalną. Co istotne, oba państwa nie mogły zbyt agresywnie reagować na posunięcia drugiej strony, gdyż narażałoby to je na straty, jednak cały czas musiały być gotowe do odpowiednich działań na wypadek zaostrzenia sytuacji ${ }^{35}$.

Narastające problemy i wyzwania między Pekinem a Waszyngtonem zostały określone przez Wang Jisi, dziekana Wydziału Stosunków Międzynarodowych Uniwersytetu Pekińskiego i Keenetha Lieberthala z Brooking Institute w Waszyngtonie mianem „strategicznej nieufności”. Brak zaufania miał być wynikiem doświadczeń historycznych, które wskazywały na fakt, iż Stany Zjednoczone wybrały niewłaściwą drogę rozwoju i ,są po złej stronie historii”. Taka percepcja uruchamiała mechanizm współpracy z państwami rozwijającymi się, którego celem było ograniczanie wpływu demokracji liberalnej, zwłaszcza po 2008 r., kiedy powszechne stało się przekonanie, że Chiny są mocarstwem. Uważają one USA za mocarstwo upadające, które pogrążone w chaosie finansowym, będzie elementem destabilizującym scenę międzynarodową. Postrzeganie Ameryki w dalszym ciągu ma bardzo konserwatywny wydźwięk. Większość elit i badaczy podziela pogląd o chęci ,westernizacji” i podziału Chin, a za dowód tego uważa się zaangażowanie Waszyngtonu w czasie „kolorowych rewolucji”. Do tego nakładają się ambicje Chińskiej Armii Ludowo-Wyzwoleńczej, chcącej dominować na wodach Azji Wschodniej, co w dalszej konsekwencji może prowadzić do zachwiania wolności żeglugi na tym obszarze ${ }^{36}$. Pekin uważał zatem politykę amerykańską wobec Chin za silnie zideologizowaną i opartą na liberalnej, amerykańskiej wizji świata. W tym wypadku zarówno Republikanie, jak i Demokraci są postrzegani z tego samego punktu widzenia. Ameryka, z jednej strony, promuje wolny handel, jednak w przypadku chińskim prowadzi politykę ideologicznej walki handlowej. W tej sytuacji Chińska Republika Ludowa musi przede wszystkim liczyć się z amerykańskim Kongresem, gdzie, bez względu na opcję polityczną, panuje przekonanie o rywalizacji gospodarczej. W tym przypadku Chiny powinny podjąć działania na rzecz stworzenia aktywnego lobbingu w amerykańskim parlamencie ${ }^{37}$. Istotne jest również zachowanie stabilnego wzrostu gospodarczego i dostępu do złóż zasobów

35 Ibidem, s. 38-39.

36 K. Lieberthal, Wang Jisi, Addressing U.S.-China Strategic distrust, Brooking Institute, March 2012, http://www.brookings.edu/ /media/research/files/papers/2012/3/30\%20us\%20china\%20lieberthal/0330_china_lieberthal.pdf [dostęp 11.11.2012].

37 Zhang Jianxin, Aobama zhengfu dui Hua maoyi zhence yu Zhong Mei jinmao guanxi [Polityka handlowa administracji Obamy i chińsko-amerykańskie relacje handlow]), „Guoji Luntan” 2009, no. 4, s. 30-31 oraz 34-35. 
naturalnych, a przez to wpływanie na ceny surowców na rynkach światowych. Od 1993 r. Chiny, stając się państwem-importerem netto ropy, a od 2003 r. drugim największym konsumentem ropy po Stanach Zjednoczonych, musiały stworzyć warunki, w których miałyby istotny wpływ na międzynarodowe rynki paliwowe. W tym przypadku relacje z innymi państwami-producentami ropy naftowej i gazu ziemnego, takimi jak Rosja czy Iran, oraz próby inwestycji w amerykańskie firmy naftowe stają się ważnym narzędziem zmierzającym w kierunku wywierania presji oraz kreowania korzystnych cen ropy na rynkach światowych ${ }^{38}$.

Oprócz wskazywanych problemów gospodarczych, zdaniem respondentów w dużych miastach chińskich, istotne miejsce zajmuje kwestia Tajwanu. Mimo podpisanych trzech komunikatów gwarantujących politykę ,,jednych Chin”, Stany Zjednoczone w dalszym ciągu utrzymywały nieformalne relacje z Formozą. W Pekinie, Szanghaju, Wuhanie i Chongqingu w blisko 60\% respondenci wskazali na ten problem jako główny w kontaktach z Waszyngtonem. Nieco inaczej na zagadnienie Tajwanu patrzyli mieszkańcy Kantonu - tylko 33,2\% uznało, iż jest to poważny problem, warunkujący relacje bilateralne. $Z$ kolei jako jedyni uznali, że zagadnienia ideologiczne mogą negatywnie wpływać na stosunki bilateralne. W porównaniu do badań z 2007 r. diametralnie zmalała rola problemu tajwańskiego, wówczas wynosiła ponad $70 \%$, podczas gdy w badaniach z $2008 \mathrm{r}$. $-51,8 \%$. Wzrosło natomiast uznanie dla problemów gospodarczych, z 37\% do ponad $54 \%{ }^{39}$.

W społeczeństwie chińskim coraz ważniejszą rolę odgrywają nastroje pronarodowe czy wręcz nacjonalistyczne. Jest to niewątpliwie związane z procesem tworzenia państwa narodowego, a co za tym idzie, naturalnego podsycania takich nastrojów. Te najpełniej były egzemplifikowane w publikowanych pracach chińskich wojskowych, takich jak Li Mingfu, oraz przez tzw. nową lewicę, która wykorzystując media internetowe, promowała idee ,wielkohańskiego nacjonali-

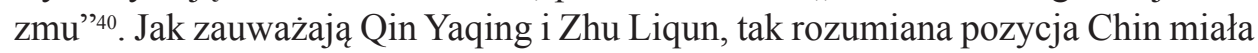
stanowić podstawy do agresji i nacjonalizmu, nietolerującego i nieakceptującego interesów innych podmiotów. Chiny powinny podkreślać swoją przynależność i zaangażowanie w sprawy międzynarodowe, co miało niwelować negatywny wpływ rosnącej asertywności. Tu zatem dochodziło do trudnej do zdefiniowania interakcji między chińskim społeczeństwem a rządzącymi. Nastroje antyzachodnie, przejawiające się głównie w postawach antyamerykańskich, były wręcz tono-

38 Wang Lianhe, Jinzheng yu hezuo Zhong Mei guanxi zhong de yinsu [Rywalizacja i współpraca. Czynniki sprawcze w stosunkach chińsko-amerykańskich], „Fudan Xuebao. Shehui kexue bao” 2010, no. 2, s. 17-20.

39 Huanqiu Shibao diaocha: renwei Zhongguo shi shijie qiangguo de renshu xiafeng [Raport Global Times: Spada liczba uznających Chiny za mocarstwo], http://news.sohu.com/20071228/ n254355301_1.shtml [dostęp 1.06.2010].

40 J. Rowiński, op. cit., s. 246-249. 
wane przez władze w Pekinie, które próbowały ograniczać możliwość konfliktu z Waszyngtonem ${ }^{41}$.

Stosunki amerykańsko-chińskie charakteryzują się zatem zarówno rywalizacją, jak i współpracą. Ta pierwsza wynika z konfliktu ideologicznego oraz różnic będących wynikiem odmiennych doświadczeń historycznych i cywilizacyjnych, a także geopolitycznej rywalizacji na Oceanie Spokojnym i w sporze o status Tajwanu. Z drugiej jednak strony ma miejsce współpraca, dzięki postępującej współzależności gospodarczej, a także poszukiwanie płaszczyzn dialogu w celu minimalizowania możliwości wybuchu konfliktu zbrojnego ${ }^{42}$.

W tak definiowanych okolicznościach u podstaw narzędzi wykorzystywanych w polityce amerykańskiej Pekinu legło przekonanie o konieczności odsuwania czy wręcz eliminacji szerszego konfliktu z Waszyngtonem. W tym kontekście podstawowym zadaniem chińskiej polityki staje się równoważenie potencjału amerykańskiego w oparciu o narzędzia kulturowe, ideologiczne czy gospodarcze, stosowane zarówno wobec Stanów Zjednoczonych, jak i amerykańskich sojuszników w skali globalnej, a także modernizację sił zbrojnych jako elementu odstraszania oraz próby uzależnienia amerykańskiej polityki w regionie Azji i Pacyfiku od wielostronnych inicjatyw Pekinu. W swoich działaniach Chiny przede wszystkim próbują równoważyć wpływy amerykańskie przez redukcję gospodarczego znaczenia USA w regionie, uniemożliwienie remilitaryzacji Japonii, połączonej sojuszem z Waszyngtonem, oraz uniemożliwienie partnerstwa Rosji i państw Azji Południowo-Wschodniej ze Stanami Zjednoczonymi, z drugiej zaś strony są świadome istotnej wagi Ameryki jako czynnika stabilizującego i mogącego wpływać na politykę państw w regionie Azji Wschodniej ${ }^{43}$.

\section{Chiński model i efektywność promocji kultury}

Do narzędzi ideologicznych wykorzystywanych pragmatycznie należy zaliczyć dążenie Pekinu do stworzenia alternatywnego modelu rozwoju oraz promocję kultury poprzez tworzenie Instytutów Konfucjusza ${ }^{44}$. Należy uznać, że w przypadku relacji z Waszyngtonem narzędzia te wykorzystywane są w celu

${ }^{41}$ Qin Yaqing, Zhu Liqun, Qin Guojizhuyi yu Zhongguo waijiao [Nowy internacjonalizm i dyplomacja Chin], [w:] Zhongguo xuezhe lun qianqiu hua yu zizhu [Chińscy badacze o globalizacji i samorządzaniu], ed. Yu Keping, Arif Dirlik, Chongqing Chubanshe, Chongqing 2008, s. 194.

42 Yuan Peng, Sino-American Relations: new chances and new challenges, „Australian Journal of International Affairs" 2007, no. 1, s. 99-100.

${ }^{43}$ W. Bert, op. cit., s. 94-95 oraz Fu Limin (Chas W. Freeman), Dui Zhong Mei guanxi bianhua de zhanwang [Projekcja zmian w stosunkach chińsko-amerykańskich], „Meiguo Yanjiu” 2009, no. 1, s. $8-10$.

44 Por. B. Góralczyk, Chiński feniks, Paradoksy wschodzacego mocarstwa, Wydawnictwo Sprawy Polityczne, Warszawa 2010, s. 241-274. 
ograniczenia wpływu Ameryki na chiński system polityczny, a docelowo do zachowania odrębności systemowej ${ }^{45}$. Koncepcja „socjalizmu z chińską specyfiką” - „chińskiego modelu rozwoju” spotkała się z dużym zainteresowaniem zarówno polityków, jak i naukowców. Doszukiwano się mocnych stron chińskiej ścieżki rozwoju, jak i sygnalizowano słabe punkty w modelu chińskiej transformacji. Jak zwraca uwagę Arif Dirlik, taki model staje się ograniczony jedynie do pewnego obszaru, nie roszcząc sobie praw do uniwersalnej ścieżki rozwoju. W tym kontekście Chiny, podobnie jak inne reżimy autorytarne Azji Wschodniej: Japonia przed 1945 r czy Korea Południowa, Tajwan do lat 80. XX w., osiągnęły relatywnie szybki wzrost ekonomiczny przy braku zmiany systemu politycznego. Należy jednak pamiętać, iż państwa te wpisywały się w „międzynarodowy podział pracy" ${ }^{46}$. Chiński model definiowany jest głównie w kontekście negacji wartości zachodniego kapitalizmu i gospodarki neoliberalnej. Z drugiej strony, jak wskazywał Joshua Ramo w 2004 r., ,konsensus pekiński” jest oparty na mechanizmach tworzenia podstaw sprawiedliwego ładu gospodarczego świata, a także nadrzędnej roli państwa w gospodarce narodowej. Stanowi to wyzwanie dla Stanów Zjednoczonych, pokazujące, że rozwój gospodarczy niekoniecznie musi być związany z transformacją polityczną i demokracją jako systemem politycznym. $\mathrm{Z}$ tego punktu widzenia korzystna dla polityki Chin była negatywna ewaluacja „konsensusu waszyngtońskiego" w państwach rozwijających się, m.in. w Ameryce Południowej.

Model chiński, jak przekonuje Zhao Suisheng, charakteryzował się głównie daleko idącym pragmatyzmem oraz ostrożnością w podejmowaniu reform, dominującą rolą państwa w polityce makroekonomicznej i selektywnym wyborem elementów gospodarki liberalnej ${ }^{47}$. Dodatkowym elementem wskazywanym przez chińskich badaczy stawał się fakt, iż „model rozwoju” został narzucony przez dyskurs zachodni, a Chiny permanentnie się transformujące nie mają ochoty na jasne i klarowne definiowanie własnego modelu. Ten miał być bowiem wypadkową dalszego pragmatycznego rozwoju. Dodatkowo, jak stwierdza Shaun Breslin, takie hasła były jedynie wyrażeniem pewnych założeń politycznych czy wręcz polityki życzeniowej władz w Pekinie ${ }^{48}$. Chiński model stał się zatem narzędziem określanym w literaturze mianem ,pragmatycznego nacjonalizmu”. Oparty został

${ }^{45}$ C.X. George Wei, Engagment or Sanctions? U.S. Economic Diplomacy toward China since the Cold War, [w:] Challenges to Chinese Foreign Policy..., s. 253-268.

46 A. Dirlik, The Idea of a „Chinese Model”: A Critical Discussion, „International Critical Thought" 2011, no. 1-2, s. 129-137.

47 Zhao Suisheng, The China Model of Development: Can It Replace Western Model of Modernization, [w:] In Search of China's Model of Development Model, Beyond the Beijing Consensus, ed. by P. Hsu, Yu-shan Wu, Zhao Suisheng, Routledge, New York-London 2011, s. 60-62.

48 S. Breslin, The „China Model” and the Global Crisis: From Friedrich List to a Chinese Mode of Governance?, http://www.eu-asiacentre.eu/documents/uploads/pub_17_breslin_in_ia.pdf [dostęp 12.12.2012]. 
przede wszystkim na poglądzie o ,unikalności Chin” i narzuceniu „światu zewnętrznemu" dyskursu, którego przesłanie można streścić do następującej frazy: Chiny są piękne i wspaniałe, z długą i bogatą tradycją, historią i kulturą, rządzone w celu osiągania nowych celów. Co ważne, kraj ten posiada odrębną ścieżkę rozwoju, określaną tu mianem ,socjalizmu z chińską charakterystyką”. Taki właśnie nacjonalizm charakteryzował się tonowaniem nastrojów nacjonalistycznych, a kładł nacisk na pragmatyzm chińskich reform, który wyrażał się w prowadzeniu reform zgodnie z możliwościami i stanem państwa ${ }^{49}$.

Powstałe okoliczności dawały swobodę eksponowania drogi rozwoju Chin jako alternatywnego modelu. „Chiński model” i ,konsensus pekiński” na stałe wpisały się we współczesny dyskurs. Model chiński miał stanowić o równym i wysokim wzroście gospodarczym. W tym kontekście procesy prywatyzacji i wolnego handlu powinny być podejmowane w szczególnie ostrożny sposób i pod stałą kontrolą państwa. Najlepszym sposobem było nawiązanie do idei reform Deng Xiaopinga ,metody małych kroków”, np. specjalnych stref ekonomicznych, przy jednoczesnym zapewnieniu integralności terytorialnej i interesów narodowych ${ }^{50}$. Zdaniem Xin Xiangyanga, sukces Chin wynikał z odrzucenia kopiowania innych modeli rozwoju i przyjęcia własnego, dopasowanego do warunków państwa. Drugim istotnym elementem było stwierdzenie, że oparcie się na rozwoju gospodarki warunkowało dalszy rozwój, w tym systemu politycznego, społecznego czy kultury ${ }^{51}$. W tym kontekście krytykowano błędne kalkulacje Francisa Fukuyamy, a także podkreślano znaczenie sukcesu chińskiego jako elementu podważającego zachodnie spojrzenie na modernizację i rozwój oraz „sinizację marksizmu” jako obronę przed okcydentalizacją Chin $^{52}$. Taka sytuacja dawała podstawy do wzmocnienia sojuszu państw rozwijających się i domagania się bardziej egalitarnego międzynarodowego systemu gospodarczego. W takiej sytuacji istniała możliwość promowania chińskiej mądrości i sprawiedliwego ładu oraz wyjątkowości tego kraju ${ }^{53}$.

49 Zhao Suisheng, A Nation-state by Construction: Dynamics of Modern Chinese Nationalism, Stanford University Press, Stanford 2004, s. 219-225.

50 Wang Zhijun, „Zhongguo moshi” jiju Shijie mingyun [Chiński model i przeznaczenie świata], „Shehuizhuyi Yanjiu” 2010, no. 3, s. 106-107.

51 Xin Xiangyang, Zhongguo moshi neihan tanxi [Wyjaśnianie znaczenia chińskiego modelu], „Lilun Tantao” 2010, no. 5, s. 6-7.

${ }_{52}$ Liu Tongfeng, Zhongguo moshi he jiefang sixiang [Chiński model i wyzwalanie nowych idei], „Lilun Tantao” 2010, no. 3, s. 7-8; Sun Weiping, Jiazhi chayu yu shehui hexie - quanqiuhu yu Dongya jiazhiguan [Różnice wartości i harmonia społeczna - globalizacja i wartości w Azji Wschodniej], Henan Shifan Daxue Chubanshe, Changsha 2008, s. 34-35.

53 Yan Yanming, Guoji Jinrong Weiji beijing xia de quanqiu jinrong zhili tixi zhonggou wenti yanjiu [Problemy przetrwania globalnego systemu finansowego w cieniu międzynarodowego kryzysu finansowego], [w:] Quanqiu zhili yu Zhongguo xuanze [Rząd światowy i chińskie wybory], Shishi Chubanshe, Beijing 2010, s. 88-89. 
Drugim elementem miękkiego oddziaływania, po „chińskim modelu”, jest promowanie chińskiej kultury przez Instytuty Konfucjusza i innego typu przedsięwzięcia przedstawiające Chiny, których celem jest zmiana ich obrazu w społeczeństwie amerykańskim. Mimo iż w Stanach Zjednoczonych funkcjonuje 71 Instytutów Konfucjusza, to percepcja Chin jako państwa autorytarnego, łamiącego prawa człowieka czy będącego miejscem nieetycznych praktyk biznesowych, pozostaje w dalszym ciągu ważną częścią składową chińskiego wizerunku w USA ${ }^{54}$.

Ponadto, mimo że oficjalnie Chiny dalekie są od promowania i narzucania własnych rozwiązań, głównym adresatem docelowym „chińskiego modelu” stają się państwa o podobnej do nich przeszłości, opisywanej jako państwo półkolonialne bądź kolonialne, prowadzące wojny narodowowyzwoleńcze i stające przed koniecznością modernizacji państwa po uzyskaniu niepodległości. Tworzy to sytuację, w której Chiny ideologicznie wyrównują potencjał amerykański, kontestując zasadność amerykańskiej wizji ujednolicenia politycznego świata.

Paradoksalnie, a niewykluczone, że przypadkowo i wbrew oczekiwaniom władz w Pekinie, Chiny mogą zostać uznane za rywala ideologicznego. Tym samym dalsze propagowanie własnego modelu ,socjalizmu z chińską specyfiką" może nie przynosić korzyści, a państwa Zachodu uznają Chiny za zagrożenie, rozpoczynając politykę podkopywania interesów chińskich w państwach rozwijających się.

\section{Gospodarczy multilateralizm i uzależnianie handlowe}

Przyjęta na III Plenum XI Zjazdu KPCh linia modernizacji państwa przyniosła efekty w postaci wzrostu znaczenia Chin na gospodarczej mapie świata. Pekin stał się drugą gospodarką świata, co dawało mu istotne możliwości wykorzystywania narzędzi gospodarczych, takich jak inwestycje bezpośrednie czy inwestycje na rynkach kapitałowych. Punktem wyjścia do zwiększonej aktywności gospodarczej Chin w relacjach ze Stanami Zjednoczonymi stał się niewątpliwie gospodarczy kryzys przełomu 2007 i 2008 r. Z jednej strony dokonywano negatywnych ocen procesów globalizacji, z drugiej zaś domagano się reform w międzynarodowym systemie gospodarczym, czego wyrazem była aktywna partycypacja w forum G20. Narzędzia gospodarcze, oprócz stanowienia przeciwwagi dla amerykańskiej dominacji, miały kluczowe znaczenie dla ograniczania możliwości w polityce zagranicznej USA, głównie w regionie Azji Wschodniej.

Oceniając procesy globalizacji, wskazywano, że nie prowadziły one do porządku, a wręcz przeciwnie - tworzyły chaos. Ponadto globalizacja, zdaniem wie-

54 Szerzej na ten temat patrz: 66\% - Most Americans See China as a Competitor, http://pewresearch.org/databank/dailynumber/?NumberID=1624 [dostęp 21.10.2012]. 
lu chińskich ekspertów, choć przynosiła korzyści, to jednak w głównej mierze służyła państwom rozwiniętym. To właśnie Zachód dążył do unifikacji świata pod względem gospodarczym, społecznym i politycznym, lecz zamiast wyrównania szans przynosił nierówności i konflikty ${ }^{55}$. W tej sytuacji presja na Stany Zjednoczone i wymuszanie zmiany w międzynarodowym systemie walutowym, tak by uniezależnić się od amerykańskiej waluty, stały się naturalnym narzędziem w chińskiej polityce. Było to rozumiane jako warunek reformy systemu międzynarodowego, a głównym miejscem reform powinno być forum G20, które miało odpowiadać za globalną koordynację działań finansowych. Tworzenie G20 było o tyle korzystne dla Chin, że rozkładano odpowiedzialność, a ponadto stanowiło ono dogodne miejsce dla budowania szerszej koalicji, chroniącej interesy Chin i państw rozwijających się ${ }^{56}$.

Uznawano, że G20 będzie elementem rozwiązania kryzysu, ale bez szans na stworzenie na bazie forum „rządu światowego". W takiej sytuacji forum G20 odzwierciedlało nową mapę gospodarczą świata i, co istotniejsze, było sygnałem redefinicji amerykańskiej dominacji w stosunkach międzynarodowych. Dla rozwiązania kryzysu finansowego Waszyngton nie tylko potrzebował najbogatszych państw, lecz również rynków wschodzących. Jak oceniano w Pekinie, dodatkowym elementem był fakt, że G20 składało się z bogatej grupy G8 i reszty biednych państw, wśród których jest jedno „bogate państwo”, czyli Chiny. Taka ocena stawiała Chiny już nie jako podmiot unikający brania odpowiedzialności, ale jako rzecznika, choć bardzo ostrożnego, praw państw rozwijających się. W ramach forum Chiny spełniały również rolę pośrednika i czynnika równoważącego wpływy i interesy państw zachodnich ${ }^{57}$.

Podobna sytuacja musiała prowadzić do redefinicji w globalnych strukturach gospodarczych. Znalazło to odzwierciedlenie w zmianach ich roli w Międzynarodowym Funduszu Walutowym oraz w Banku Światowym. W przypadku pierwszego zwiększono prawo głosu państw rozwijających się z 40,5\% do 42,1\%, a w Banku Światowym z 44,06\% do 47,19\%. Na tym tle najwięcej zyskały Chiny,

55 Jiang Dingyi, Guanyu Weiji xia jinrong zhuwei jingji fazhan de jige zhongdian [O wybranych problemach powrotu i dalszego rozwoju gospodarczego po kryzysie], http://www.aisixiang. com/data/29527.html [dostęp 29.01.2011].

56 Wang Guoxing, Chen Qing, G20 Jizhihua yu Quanqiu jingji zhili gaige [Instytucjonalizacja G20 i reforma globalnego systemu ekonomicznego], „Guoji Jingji Pinglun” 2010, no. 4, s. 1921 oraz Cui Zhinan, Xing Yue Cong, "G7 Shidai" dao "G20 Shidai" Guoji jinrong zhili jizhi de bianqian [Od G7 do G20. Zmiany międzynarodowego zarządzania międzynarodowym systemem finansowym], „Shijie Jingji yu Zhengzhi” 2011, no. 1, s. 138-139.

57 Cui Liru, G20 kaiqi le tansuo „,quanqiu zhili” xin lujing de jihui zhi chuang [G20 sprawdza nowe możliwości „rządu globalnego”], „Xiandai guoji guanxi” 2009, no. 11, s. 3; Yuan Peng, G20 shidai yiyi yu xianshi qishi [Znaczenie i praktyka czasów G20], „Xiandai guoji guanxi” 2009, no. 11, s. 17-18 oraz Jin Canrong, G20 de yuanqi yu qianjing [Korzenie i przyszłośc G20], „Xiandai guoji guanxi” 2009, no. 11, s. 4-5. 
których udział wzrósł do 3,997\% w MFW oraz z 2,77\% do 4,42\% w Banku Światowym. Jak zauważał Song Wei, chińskie posunięcia dyplomatyczne uzależnione były od posiadania amerykańskich obligacji oraz rezerw w dolarze amerykańskim $^{58}$. Jednak, z drugiej strony, kryzys zachodniego systemu stanowił o wzrastającej sile i pewności drogi reform obranej w $1978 \mathrm{r}$. O ile w latach 80. na reformy chińskie świat zachodni patrzył z perspektywy „końca historii”, oczekując rychłego upodobnienia się, w imię logiki liberalnego systemu, o tyle w latach 90. chiński wzrost stanowił poważny problem, podczas gdy w czasie kryzysu stawał się trudną lekcją chińskiego modelu ${ }^{59}$. Globalizacja w zakresie finansów doprowadziła do „niekończącej” się ekspansji derywatów instrumentów pochodnych, czyli opcji, kontraktów terminowych i swapów, których wartość pod koniec 2007 r. szacowano na 630 bilionów USD. Jak powszechnie oceniano, „wirtualny kapitalizm” był przyczyną problemów gospodarki światowej, wymagających zdecydowanej ingerencji państwa i stworzenia mechanizmów kontrolnych. Najlepszym przykładem dominacji „wirtualnych pieniędzy”, przytaczanym w opracowaniach chińskich, były Stany Zjednoczone. Transformacja amerykańskiej gospodarki prowadziła do spadku udziału przemysłu w globalnym PKB kraju. W 2007 r. rola sektora przemysłowego spadła z $27 \%$ do $11,7 \%$ udziału w amerykańskim PKB, podczas gdy wirtualne aktywa z $11,37 \%$ do $20,67 \%$, co stawiało pod znakiem zapytania możliwość odrodzenia się kapitalizmu ${ }^{60}$.

Stwarzało to dogodną okazję dla ekspansji chińskich narzędzi gospodarczych, opartych na tworzeniu stref wolnego handlu, w tym przede wszystkim z państwami regionu Azji Wschodniej, oraz polityki walutowej banku centralnego Chin. Głównym punktem było jednak powolne włączanie amerykańskich sojuszników w „,chiński krąg gospodarczy”. Kluczowe było tu uzależnienie gospodarek Japonii i Korei Południowej od Chińskiej Republiki Ludowej.

Drugim istotnym punktem miały stać się chińskie inwestycje w Stanach Zjednoczonych. Tu jednak, z uwagi na brak transparentnych reguł wewnątrz Chin, amerykańscy politycy nie są skłonni do akceptowania chińskich inwestycji. Najlepszym tego przykładem było zablokowanie inwestycji w amerykański przemysł petrochemiczny. Kongres uniemożliwił w 2005 r. zakup akcji Unocal przez chiński

58 Song Wei, Guoji jinrong weiji yu Meiguo de danji diwei ([Międzynarodowy kryzys finansowy i unilateralna pozycja Stanów Zjednoczonych], [w:] Guoji jinrong weiji, Meiguo baquan yu Dong Ya jingji hezuo [Międzynarodowy kryzys finansowy, hegemonia Stanów Zjednoczonych i współpraca gospodarcza w Azji Wschodniej], Shijie Zhishi Chubanshe, Beijing 2010, s. 67-77.

59 Gao Fei, Hexie shijie yu junzi guojia Guanyi guoji tixi yu Zhongguo de sikao [Harmonijny świat i państwo szlachetne. O międzynarodowym systemie i chińskich refleksjach], Shijie Zhishi Chubanshe, Beijing 2011, s. 69-71.

${ }^{60}$ Liu Zhiming, Jinrong weiji dongtuo le shijie dui xifang ziben zhuyi zhidu de xiangxin [Kryzys finansowy podważa wiarygodność zachodniego kapitalizmu], http://www.aisixiang.com/ data/37552.html [dostęp 11.09.2012]. 
CNOOC, a także zakup Meyera przez chińską grupę Haier ${ }^{61}$. Niemniej jednak, mimo początkowych oporów, sytuacja w Stanach Zjednoczonych zmieniała się na niekorzyść Waszyngtonu. Najlepszym tego przykładem było rosnące rokrocznie ujemne saldo, które osiągnęło w 2011 r. prawie 300 mld USD (por. tabela 2.1). Tym samym Pekin stwarzał dogodny mechanizm oddziaływania w polityce amerykańskiej. Chińska gospodarka, oparta na modelu proeksportowym, potrzebowała ingerencji państwa w sztuczne podtrzymywanie kursu waluty chińskiej. Amerykanie próbowali doprowadzić do negocjacji w sprawie rewaluacji RMB, postulując nałożenie ceł na towary eksportowane przez Chiny w wysokości 27,5\%. Wobec tego w 2005 r. Chiny wprowadziły kurs płynny regulowany, a do 2008 r. kurs względem dolara umocnił się o blisko 21\%, z 8,28 RMB do 6,83 RMB ${ }^{62}$.

Tabela 2.1.

Handel zagraniczny w stosunkach dwustronnych

\begin{tabular}{|c|c|c|c|}
\hline Rok & Eksport USA & Import USA & Bilans w handlu dwustronnym \\
\hline 1980 & 3,8 & 1,1 & 2,7 \\
\hline 1985 & 3,9 & 3,9 & 0 \\
\hline 1990 & 4,8 & 15,2 & $-10,4$ \\
\hline 1995 & 11,7 & 45,6 & $-33,8$ \\
\hline 2000 & 16,3 & 100,1 & $-83,8$ \\
\hline 2005 & 41,8 & 243,5 & $-201,6$ \\
\hline 2006 & 55,2 & 287,8 & $-232,5$ \\
\hline 2007 & 65,2 & 321,5 & $-256,3$ \\
\hline 2008 & 71,5 & 337,8 & $-266,3$ \\
\hline 2009 & 69,6 & 296,4 & $-226,3$ \\
\hline 2010 & 91,9 & 364,9 & $-273,1$ \\
\hline 2011 & 103,9 & 393,3 & $-295,5$ \\
\hline
\end{tabular}

Źródło: U.S.-China Trade Issue, www.fas.org/sgp/crs/row/RL33536.pdf [dostęp 12.01.2013].

Kolejnym mechanizmem wywierania presji na Waszyngton stało się umiędzynarodowienie chińskiej waluty renminbi - yuana. Negocjując warunki włączenia go do międzynarodowych rynków walutowych, Chiny przyjęły strategię „wykupienia" Ameryki, by w ten sposób prowadzić do zmian zasad gry rządzących

${ }_{61}$ CNOOC Withdraws Unocal Bid, http://www.china.org.cn/english/2005/Aug/137165.htm [dostęp 11.12.2012].

62 A. Gradziuk, Problem zaniżonego kursu chińskiej waluty, „Biuletyn PISM” 2010, nr 72 (620), s. 1-3. 
mechanizmami gospodarki światowej. Między 2007 a 2011 r. udział Chin w amerykańskim rynku papierów dłużnych, mimo że wzrósł nieznacznie, bo tylko o ponad $3 \%$, to całościowa kwota wyniosła ponad miliard sto milionów USD, wzrastając o prawie $120 \%$ (por. tabela 2.2 i 2.3 ). Tym samym powstała sytuacja, w której to Pekin, wraz z Japonią, państwami OPEC, Brazylią, Rosją oraz Tajwanem, stawał się sponsorem amerykańskiej aktywności międzynarodowej, w tym wojen z terroryzmem prowadzonych w Afganistanie i Iraku. Strategia ta dała również pozytywne efekty w postaci dostępu do chińskich inwestycji bezpośrednich na rynku amerykańskim. Mimo nominalnego wzrostu między 2009 a 2011 r. chińskie inwestycje stanowią śladowy ułamek w porównaniu do $95 \%$ inwestycji europejskich w Ameryce. W obliczu kryzysu gospodarczego oraz uzależnienia od walutowych manewrów, Chiny uzyskały możliwość inwestycji w USA. Inwestycje te koncentrowały się głównie na amerykańskim przemyśle paliwowym. W 2010 r. CNOOC zakupił 33\% akcji Chesapeake Energy, a Sinopec nabył udziały w Devon Energy, zapewniając sobie jednocześnie dostęp do amerykańskich złóż m.in. w stanach Ohio i Michigan ${ }^{63}$.

Tabela 2.2.

Udział państw w amerykańskim rynku dłużnym (grudzień 2007 r.)

\begin{tabular}{|c|c|c|}
\hline \multicolumn{3}{|c|}{ Grudzień 2007 r. } \\
\hline Państwo & Kwota & $\begin{array}{l}\text { Udział w amerykańskim rynku dłużnym } \\
(\mathrm{w} \%)\end{array}$ \\
\hline Japonia & 581,2 & 24,70 \\
\hline Chiny & 477,6 & 20,30 \\
\hline Wielka Brytania & 158,1 & 6,70 \\
\hline państwa OPEC & 137,9 & 5,90 \\
\hline Brazylia & 129,9 & 5,50 \\
\hline Karaiby & 116,4 & 5,00 \\
\hline Luksemburg & 69,7 & 3,00 \\
\hline Hongkong & 51,2 & 2,20 \\
\hline Niemcy & 41,7 & 1,80 \\
\hline Singapur & 39,8 & 1,70 \\
\hline
\end{tabular}

Źródło: http://www.treasury.gov/resource-center/data-chart-center/tic/Documents/mfh.txt [dostęp 12.10.2013].

63 Sinopec, Devon in \$2.2 Bln Shale Deal, http://www.reuters.com/article/2012/01/03/devonenergycorp-idUSL3E8C36L720120103 [dostęp 11.11.2012] oraz CNOOC to Pay \$1.1 Billion forStake in Chesapeake Unit, http://www.reuters.com/article/2010/10/11/us-chesapeake-cnooc-idUSTRE69A01M20101011 [dostęp 11.11.2012]. 
Tabela 2.3.

Udział państw w amerykańskim rynku dłużnym (grudzień 2011 r.)

\begin{tabular}{|c|c|c|}
\hline \multicolumn{3}{|c|}{ Grudzień 2011 r. } \\
\hline Państwo & Kwota & $\begin{array}{l}\text { Udział w amerykańskim rynku dłużnym } \\
(\text { (w \%) }\end{array}$ \\
\hline Chiny & $1,151,9$ & 23,10 \\
\hline Japonia & $1,058,0$ & 21,20 \\
\hline państwa OPEC & 258,3 & 5,20 \\
\hline Brazylia & 226,9 & 4,50 \\
\hline Karaiby & 226 & 4,50 \\
\hline Tajwan & 177,3 & 3,60 \\
\hline Rosja & 149,5 & 3,00 \\
\hline Luksemburg & 147,6 & 3,00 \\
\hline Szwajcaria & 142,3 & 2,90 \\
\hline Belgia & 135,2 & 2,70 \\
\hline
\end{tabular}

Źródło: jak w tab. 2.2.

Innym elementem wywierania, w sposób pośredni, presji gospodarczej na Stanach Zjednoczonych była chińska aktywność w ramach tworzenia stref wolnego handlu. Wykorzystując swój potencjał, Chiny podjęły starania tworzenia stref wolnego handlu. W dalszej perspektywie miało to im zapewnić swobodny dostęp do rynków, a tym samym ograniczać możliwość dominacji amerykańskiej w regionie. W tym kontekście Chiny dysponują ogromnym potencjałem prowadzenia polityki pośrednio ograniczającej swobodę ruchu Stanów Zjednoczonych. Stwarza to okoliczności, w których, jak stwierdza Ian Bremmer, tworzą się mechanizmy oparte zarówno na rywalizacji, jak i wzajemnych konsultacjach. Chińska ekspansja, m.in. w Wenezueli, rodzi poważne wyzwania dla amerykańskiej dominacji w gospodarce światowej ${ }^{64}$. Dlatego tworzenie stref wolnego handlu przez Chiny i kwestia amerykańskiej reakcji stają się istotnym elementem nowego układu międzynarodowego. Władze w Pekinie, tworząc zręby współpracy gospodarczej w regionie, kreują mechanizmy balansujące rolę militarną Stanów Zjednoczonych w Azji Wschodniej. To podpisane deklaracje między Chinami, Japonią i Koreą Południową oraz państwami ASEAN wymuszają na władzach w Waszyngtonie poszukiwanie odpowiednich narzędzi gospodarczych. Tym samym Ameryka zmuszona jest do stworzenia stref na podobnych warunkach,

${ }^{64}$ H. Harding, China Goes Global Implications for the United States, „National Interests” 2006, no. 5, s. 57-66. 
oferując dogodne warunki handlowe państwom, które już zawarły bądź negocjują umowy z Chinami. Takim krokiem było podpisanie w maju 2012 r. wstępnej umowy o współdziałaniu w sprawach gospodarczych między Chinami, Japonią i Koreą Południową ${ }^{65}$. Co ważne, strefy wolnego handlu stały się jednym z podstawowych mechanizmów gospodarczych, a w samej Azji Wschodniej między 2000 a $2012 \mathrm{r}$. liczba podpisanych porozumień o strefach wolnego handlu wzrosła $\mathrm{z}$ trzech do $71^{66}$. Wymuszanie na Ameryce podobnych ruchów prowadzi, z jednej strony, do dalszego uzależniania, z drugiej zaś - otwiera nowe pola rywalizacji o wpływy w regionie. W tym kontekście Stany Zjednoczone podjęły próbę integracji gospodarczej w ramach TPP Trans-Pacific Strategic Economic Partnership Agreement. Z punktu widzenia polityki regionalnej Pekinu Amerykanie, próbując włączyć w porozumienie o wolnym handlu Wietnam (negocjacje od 2008 r.) czy Malezję (negocjacje od 2010 r.), prowadzili do równoważenia wpływów chińskich w regionie Azji Południowo-Wschodniej ${ }^{67}$. W takich kategoriach rywalizacji gospodarczej postrzegany jest amerykański „zwrot w kierunku Azji”. Uznanie Azji i Pacyfiku za rdzeń amerykańskiej polityki zagranicznej stworzyło określone nowe wyzwania dla narzędzi stosowanych przez Chiny w prowadzeniu relacji zewnętrznych ${ }^{68}$.

\section{Modernizacja chińskich sił zbrojnych}

Kolejnym narzędziem w chińskiej polityce wobec Stanów Zjednoczonych jest rozbudowa i modernizacja Chińskiej Armii Ludowo-Wyzwoleńczej (ChAL-W). Jak zapewniają chińskie elity, ma ona charakter defensywny, a chińskie deklaracje o pokojowym wykorzystaniu sił zbrojnych nie powinny budzić wątpliwości. Z perspektywy prowadzenia polityki zagranicznej nowoczesne siły zbrojne spelniają jednak rolę podwójną: po pierwsze, dążą do równoważenia amerykańskiej dominacji, a po wtóre, mają służyć ochronie coraz bardziej globalnych interesów chińskich. W tym kontekście, jak zauważa David Shambaugh, ważnym procesem była zmiana wśród chińskich elit wojskowych postrzegania specyfiki konfliktów. Od czasów Mao Zedonga dokonano zwrotu od „wojny ludowej”, przez „wojnę ludową w nowoczesnych warunkach”, „wojnę ograniczoną”, aż do „wojny

${ }_{65}$ Signing of the Japan-China-Korea Trilateral Investment Agreement, http://www.mofa.go. jp/announce/announce/2012/5/0513_01.html [dostęp 10.12.2012].

${ }_{66}$ P.B. Rana, A Region-wide Free Trade Agreement in Asia, http://www.voxeu.org/article/freetrade-agreement-asia [dostęp 11.12.2012].

${ }_{67}$ Szerzej na ten temat patrz: http://www.ustr.gov/tpp [dostęp 12.12.2012].

68 Zhu Feng, Aobama zhengfu ,zhuansheng Yazhou” zhanlue yu Zhong Mei guanxi [Strategia powrotu do Azji administracji Obamy i stosunki chińsko-amerykańskie], „Xiandai Guoji Guanxi” 2012, no. 4, s. 5-6. 
ograniczonej z użyciem nowoczesnych technologii"69. W procesie modernizacji ograniczano też liczbę personelu wojskowego przy jednoczesnej profesjonalizacji rekrutacji i szkolenia przyszłych wojskowych. Taka polityka niewątpliwie wymagała zmian w strukturze budżetu obronnego, a także wzrostu nakładów na obronę $^{70}$. Ważna jest przy tym zmiana projekcji roli Chińskiej Armii Ludowo-Wyzwoleńczej. Tu doszło bowiem do znaczącej redefinicji. Wzrastające interesy gospodarcze chińskich przedsiębiorstw oraz przyjęta w 2002 r. strategia go global stworzyły podstawy do zwiększenia stref będących przedmiotem zainteresowania władz w Pekinie. W konsekwencji prowadziło to do zwiększania nakładów na chińską marynarkę wojenną i lotnictwo wojskowe ${ }^{71}$. Ponadto modernizacja chińskich sił zbrojnych, w kontekście amerykańskiej polityki budowy globalnej tarczy antyrakietowej Theather Missile Defence, miała za zadanie budowę efektywnego zaplecza polityki obronnej, a także koncentrowała się na odstraszaniu ewentualnego ataku amerykańskiego ${ }^{72}$.

Jak wskazuje analiza układu personalnego, zarówno na XVII, jak i XVIII Zjeździe Komunistycznej Partii Chin, tok decyzyjny w polityce zagranicznej przechodził w ręce lobby wojskowego i naftowego. W Stałym Komitecie Biura Politycznego - najważniejszego ciała decyzyjnego w Chinach - zarówno w trakcie XVII, jak i XVIII kadencji nie znalazły się osoby związane z prowadzeniem polityki zagranicznej. Wskazywało to na proces jeszcze większego utajnienia procesu decyzyjnego, a narastające konflikty na spornych obszarach Morza Południowochińskiego oraz wysp Diaoyu/Senkaku interpretowane były jako wzrost znaczenia struktur siłowych w procesie decyzyjnym ${ }^{73}$. Takie zmiany w chińskiej percepcji, mające wyraz w coraz bardziej asertywnej polityce, stawały się niebagatelnym wyzwaniem dla amerykańskiej polityki w regionie. Głównym punktem odniesienia była zatem modernizacja marynarki wojennej ChAL-W. Do podstawowych zadań modernizacji zalicza się zakup: systemów naprowadzających przeciwskrętowe pociski balistyczne (ASBMs), przeciwskrętowych pocisków manewrujących (ASCMs), pocisków manewrujących naprowadzanych z ziemi (LACMs), samolotów bezzałogowych, okrętów, fregat oraz zintegrowanych systemów wsparcia dowodzenia

69 D. Shambaugh, Modernizing China's Military. Process, Problems and Prospects, University of California Press, Berkeley-Los Angeles-London 2002, s. 60-61.

70 D. Lampton, The Three Faces of Chinese Power. Might, Money, and Minds, University of California Press, Berkeley-Los Angeles-London 2008, s. 42-44.

71 Szerzej na temat spraw bezpieczeństwa Chińskiej Republiki Ludowej patrz: D. Mierzejewski, Koncepcje bezpieczeństwa Chińskiej Republiki Ludowej, [w:] Bezpieczeństwo międzynarodowe po zimnej wojnie, red. R. Zięba, Wydawnictwo Naukowe i Akademickie, Warszawa 2007, s. 195 i n.

72 D. Lampton, op. cit., s. 45-46.

73 O takim procesie może świadczyć deklaracja przedstawiona w referacie partyjnym przez Hu Jintao 8 listopada 2012 r.: „Poprawiamy efektywność eksploracji złóż morskich, rozwijamy gospodarkę morską i ochronę przyrody morskiej, chronimy narodowe interesy w przestrzeni morskiej, budując mocarstwo morskie (haiyang qiangguo)”. Por. „Renmin Ribao”, 14.11.2012, s. 1-5. 
i zobrazowania pola walki C4ISR. Prócz tego proponowane są nowe rozwiązania logistyczne, nowoczesne zarządzanie personelem, a także nowa doktryna morska ${ }^{74}$. Z punktu widzenia narzędzi chińskiej polityki amerykański powrót do Azji określany był mianem pivot to Asia. W deklaracji z listopada 2011 r. Stany Zjednoczone ponownie uznały, że Azja i Pacyfik będą głównym przedmiotem zainteresowania amerykańskiej polityki - jej rdzeniem. Kompleksowa inicjatywa amerykańska, która stanowiła o powtórnym przejściu do inicjatywy równoważenia potencjału chińskiego, wskazywała na konieczność użycia narzędzi związanych głównie $\mathrm{z}$ chińskimi siłami zbrojnymi ${ }^{75}$. Zmiany w amerykańskiej polityce odzwierciedlały rosnące znaczenie regionu Azji i Pacyfiku oraz rozpoczynały nowy element strategii w okresie ,poirackim i poafgańskim”. W swoim wystąpieniu w Canberze Barack Obama wskazał Azję jako strategiczny obszar w polityce amerykańskiej. Przeniesienie punktu ciężkości i wsparcie, zarówno gospodarcze, jak i wojskowe, państw regionu stawało się zasadniczym wyzwaniem prowadzenia pokojowej dyplomacji chińskiej. Reakcja na amerykańskie zacieśnianie sojuszy z Myanmarem, Tajlandią czy Wietnamem musiała być zdecydowana, stąd też co roku podnoszono kwoty w chińskim budżecie obronnym ${ }^{76}$. Jak stwierdza Zhu Feng z Chińskiej Akademii Nauk Społecznych, w Chinach zaczęto podejrzewać, iż amerykański pivot to Asia będzie tworzył okoliczności, w których Ameryka będzie poszukiwać płaszczyzn dla kolejnego „wyścigu zbrojeń” ${ }^{77}$. Objawiło się to również w bardziej asertywnych wypowiedziach chińskich polityków oraz w publikacjach oficjalnych mediów Komunistycznej Partii Chin ${ }^{78}$.

$\mathrm{Z}$ tej perspektywy silna pozycja militarna buduje pozycję Chin w rozmowach ze Stanami Zjednoczonymi na szczeblu wojskowym. Od 2005 r., kiedy wizytę w Chinach złożył amerykański sekretarz obrony Donald Rumsfeld, oba państwa rozpoczęły regularne konsultacje w sferze wojskowej. Rozpoczęło to regularne wizyty wojskowe w obu państwach, co dawało możliwość unikania nieporozumień, a także przypadkowych incydentów militarnych, takich jak w kwietniu 2001 r. z amerykańskim samolotem EP-3. W tym kontekście wzmożona współzależność staje się gwarantem unikania szerszego konfliktu, który w relacjach chińsko-amerykańskich jest głównym punktem wyjścia stosowanych narzędzi.

74 R. O'Rourke, China Naval Modernization: Implications for U.S. Navy Capabilities- Background and Issues for Congress, http://www.fas.org/sgp/crs/row/RL33153.pdf [dostęp 12.12.2012].

75 B. Gill, China as a Regional Military Power, [w:] Does China matter?..., s. 124-142.

76 Stany Zjednoczone posiadają personel wojskowy i bazy wojskowe w: Korei Południowej 14 baz, Japonii 17 baz, wraz z ponad 40 tys. wojskowych, Tajlandii 162 wojskowych, na Filipinach 182 wojskowych, w Singapurze jedną bazę wojskową i 157 osób personelu wojskowego. Patrz Barack Obama Says Asia-Pacific Is „Top US Priorit”, 17.11.2011, http://www.bbc.co.uk/news/ world-asia-15715446 [dostęp 11.12.2012].

77 Zhu Feng, op. cit., s. 4.

78 Por. m.in. referat Hu Jintao w czasie XVIII Zjazdu cytowany za „Renmin Ribao”, 14.11.2012, s. 1-5 oraz „Renmin Ribao”, 10.12.2012, s. 1. 
Modernizacja sił zbrojnych przyniosła efekt w postaci rozszerzenia platform dialogu na poziomie bilateralnym i multilateralnym. Z punktu widzenia prób dialogu na forach międzynarodowych należy podkreślić, iż takim stał się strategiczny dialog Shangri La w Singapurze. Prócz możliwości wyrażenia własnych ocen sytuacji, Stany Zjednoczone i Chiny w bilateralnych rozmowach na neutralnym gruncie mogą wypracowywać kompromis w kwestiach spornych. Taka formuła, wobec przesuwania się obszaru rywalizacji na Ocean Spokojny, staje się węzłowym forum strategicznym. Jak stwierdził Leon Panetta, amerykański sekretarz obrony, siły morskie USA do 2020 r. będą w 60\% rozlokowane na Pacyfiku, podczas gdy reszta na Oceanie Atlantyckim. Ameryka zatem stawia otwarcie wyzwanie wzrastającej potędze i strategii Chin, które planują wyjście na oceany ${ }^{79}$.

Budowa środków zaufania w sektorze wojskowym stawiana jest jednak przed poważnymi wyzwaniami natury strategicznej. Oprócz zwiększającej się chińskiej aktywności na polu wojskowym, powszechnie uznaje się, że problemem jest utajnianie przez Chiny spraw związanych z budżetem obronnym, co stanowi główny punkt sporny w tworzeniu wzajemnego zaufania, głównie na szczeblu wojskowym ${ }^{80}$. Z kolei w samych Chinach, w zamian za poparcie reform, władze partyjne musiały koncesjonować przedsięwzięcia wojskowych, i tak np. Sztab Generalny ChAL-W prowadzi aktywność gospodarczą w ramach China Poly Group, Huitong Corporation, Pinghe Electronic Corporation czy China Zhihua Limited Corporation ${ }^{81}$.

\section{Dyplomatyczne narzędzia budowy środków zaufania}

W ramach oddziaływania dyplomatycznego należy wskazać dwie formy aktywności chińskiej polityki zagranicznej: dążenie do wielopłaszczyznowego dialogu bilateralnego, a także tworzenie wielostronnych for z udziałem Chin i Stanów Zjednoczonych. Niewątpliwie takie formy mają prowadzić do budowy środków zaufania, a przez to do ograniczania możliwości wybuchu konfliktu. Obok wizyt najważniejszych polityków, kluczowe miejsce od 2009 r. zajmuje Dialog Strategiczny oraz od 2006 r. Dialog na Wysokim Szczeblu. Utworzenie mechanizmu konsultacyjnego w zakresie spraw strategicznych i gospodarczych było odpowiedzią na wzrastającą rolę Chin, a także próbą stworzenia platformy

79 US Naval Strategy „Untimely”, Says China,

http://economictimes.indiatimes.com/news/news-by-industry/et-cetera/us-naval-strategy-untimely-says-china/articleshow/13862972.cms [dostęp 12.01.2013].

80 R. Weitz, Persistent Barriers to Sino-American Military Dialogue, „China Brief” 2006, vol. 6, http://www.jamestown.org/single/?no_cache=1\&tx_ttnews[tt_news]=32008 [dostęp 11.06.2011].

81 D. Shamabaugh, op. cit., s. 198-199 oraz China's Defense Budget, http://www.globalsecurity.org/military/world/china/budget.htm [dostęp 12.12.2012]. 
do zarządzania sprawami bilateralnymi, regionalnymi i globalnymi. Zasadniczym punktem w prowadzonym dotąd dialogu było podpisanie, $w$ trakcie trzeciej rundy Dialogu Strategicznego, porozumienia poświęconego współpracy gospodarczej, promującej zrównoważoną i stabilną wymianę handlową

Mimo że stworzona platforma daje możliwość dialogu, to jednak pojawiały się istotne problemy dotyczące jego percepcji. Podstawowym zagadnieniem jest tu inna ocena praw człowieka. Wskazywana przez Stany Zjednoczone kwestia Tybetu winna być rozpatrywana z perspektywy wolności religijnej oraz praw człowieka, podczas gdy dla Chin jest to kwestia suwerenności państwa, która nie jest przedmiotem ingerencji państw trzecich ${ }^{83}$. Dai Bingguo, podobnie jak Xi Jinping i oficjalne oświadczenie chińskiego MSZ, odrzucał presję amerykańską dotyczącą praw człowieka. Ameryka, w argumentacji chińskich polityków, nie mogła jednostronnie atakować interesów chińskich ani też wymuszać wzięcia odpowiedzialności, która wykraczała poza aktualne możliwości chińskie ${ }^{84}$. Ponadto istotnym problemem relacji dwustronnych jest brak odpowiednich instytucji odpowiedzialnych za bilateralny dialog. Jak zauważył Wang Jisi, utrudnia to rozmowy, gdyż stanowiska zajmowane przez Dai Bingguo czy Wang Qishana, reprezentujących Chiny, nie posiadały odpowiedników w Stanach Zjednoczonych, reprezentowanych przez Hilary Clinton - sekretarz stanu oraz Joe Bidena - wiceprezydenta ${ }^{85}$. Dodatkowymi elementami spornymi są różnice wzajemnych oczekiwań. Chiny domagają się przede wszystkim złagodzenia zasad amerykańskiego eksportu wysokich technologii, uznania Chin za gospodarkę rynkową, traktowania chińskich inwestorów w USA na równi z innymi oraz oddzielenia kwestii politycznych od spraw gospodarczych. Przeciwnie do wskazanych, Waszyngton domaga się aprecjacji chińskiej waluty, otwarcia rynków finansowych dla obcego kapitału oraz akceptacji międzynarodowych zasad ochrony praw intelektualnych ${ }^{86}$.

Istotna, z punktu widzenia tworzenia nowych platform współpracy i dialogu, była próba rozwiązania nuklearnego problemu Koreańskiej Republiki Ludowo-Demokratycznej. Chiny próbowały wykorzystać doświadczenia z przeszłości i wpływać w tradycyjnie chiński sposób na politykę Pjongjangu. Przede wszyst-

82 http://www.jamestown.org/uploads/media/cb_009_02.pdf [dostęp 12.12.2012].

83 Wang Jisi, Zhong Mei guanxi de fazhanqushi yu shencun yuanyin [Podstawy i tendencje w stosunkach chińsko-amerykańskich], „Dang dai Ya-tai” 2009, no. 3, s. 4-5.

84 Waijiaobu fayan ren Qin Gang jiu Meiguo wuyuan fabiao she Huaren renquna baogao huijizhe wen, 12.03.2010, [Odpowiedź rzecznika prasowego MSZ Qin Ganga na opublikowanie przez Departament Stanu USA raportu o stanie praw człowieka w Chinach], http://www.fmprc.gov. cn/chn/pds/gjhdq/gj/bmz/1206_22/fyrygth/t663675.htm [12.09.2012] oraz Waijiao fayan ren Hong Lei jiu Zhong Mei renquan duihua hui jizhe wen, 27.07.2010 [Rzecznik prasowy MSZ Hong Lei o chińsko-amerykańskim dialogu w zakresie praw człowieka], http://www.fmprc.gov.cn/chn/gxh/ tyb/fyrbt/dhdw/t956200.htm [dostęp 12.09.2012].

85 Wang Jisi, op. cit.

86 „Beijing Review”, 26.05.2011, s. 10-11. 
kim nawiązywały do przeszłości trybutarnej Korei, która począwszy od 994 r., płaciła trybut królestwu Liao, a następnie w okresie dynastii Tang obszar Korei na stałe wszedł w struktury trybutarne Chin. Po podbojach dynastii Qing, między 1636 a 1894 r. Korea wysłała około 661 dyplomatycznych misji do stolicy Chin, posiadając nawet specjalną ,ambasadę" w Pekinie ${ }^{87}$. Dodatkowym atutem Chin była pomoc dla Korei Północnej w okresie wojny koreańskiej, co miało być wykorzystane do stymulowania polityki koreańskiej w kierunku przynoszącym korzyści Chinom ${ }^{88}$. Wiosną 2003 r. podjęto próby rozmów między Waszyngtonem, Pjongjangiem i Pekinem, a 23-27 sierpnia tego roku oficjalnie zainicjowano rozmowy sześciostronne. Chiny wykorzystywały szansę zaangażowania NATO i USA w Afganistanie dla poprawy własnego wizerunku oraz stworzenia nowego wielostronnego mechanizmu konsultacji strategicznych w regionie Azji Wschodniej. Niemniej jednak, mimo podjętych działań, obie strony w innych sposób wyrażały swoje oczekiwania. Podczas gdy Waszyngton uznawał Chiny za podmiot mający istotny wpływ na reżim w Pjongjangu, Chiny starały się jak najdłużej utrzymać dogodne dla ich polityki status quo (por. tabela 2.4). Mimo iż porozumienie w sprawie rozbrojenia zostało podpisane we wrześniu 2005 r., rok później, w październiku 2006 r., Koreańska Republika Ludowo-Demokratyczna wykonała podziemny test nuklearny. W rezultacie sprawa koreańska musiała zostać umiędzynarodowiona, a prowadzone pod kuratelą Chin rozmowy traciły na znaczeniu. Pekin, jako inicjator rozmów, tracił inicjatywę w kreowaniu własnego otoczenia. Rezolucja Rady Bezpieczeństwa nr 1718 wzywała do zaprzestania prób oraz nakładała sankcje na handel z Koreą Północną, zakazując również jakiegokolwiek wsparcia w postaci szkoleń czy wymiany osobowej ${ }^{89}$. Ponadto koreańska próba była wyrazem niechęci wobec władz w Pekinie i sugerowała konieczność wznowienia bilateralnych rozmów między Waszyngtonem i Pjongjangiem ${ }^{90}$.

Proponowana formuła nie przyniosła spodziewanych rezultatów. KRL-D, po sankcjach Narodów Zjednoczonych, w kwietniu 2010 r. wycofała się z rozmów sześciostronnych, a chińska polityka uzależniania gospodarczego nie była efektywnym narzędziem w skali regionalnej ${ }^{11}$. Kolejna próba nuklearna z maja 2009 r. i sankcje zgodne z rezolucją nr 1874 po raz kolejny unaoczniły słabość bądź niechęć dyplomacji Chin do aktywnego oddziaływania na Koreę Północną.

${ }^{87}$ Qi Qingfu, Ji Chengnan, Qingdai Beijing de chaoxian shiguan [Ambasad koreańska w Pekinie w okresie dynastii Qing], „Qingdai Shi Yanjiu” 2004, no. 3, s. 107-110.

${ }_{88}$ China Commemorates 60th Anniversary of Participation in Korean War, http://news.xinhuanet.com/english2010/china/2010-10/26/c_13574898.htm [dostęp 12.12.2012].

$89 \mathrm{http}$ ://www.un.org/apps/news/story.asp?NewsID=20261\&Cr=DPRK\&Cr1 $=[$ dostęp 12.12.2012].

90 Wang Lianhe, Chaoxian wenti juejie lujing de san ge cengci xuanze [Trzy możliwości rozwiązania problemu koreańskiego], ,Xiandai Guoji Guanxi” 2009, no. 1, s. 22-24.

91 E.A. McVadon, China's Goals and Strategies for the Korean Peninsula, Planning for a Peaceful Korea, ed. H.D. Sokolski, Strategic Studies Institute, Carlisle Barracks, PA. 2001, s. 135. 
Tabela 2.4.

Pozycja KRL-D, USA i ChRL w rozmowach sześciostronnych

\begin{tabular}{|l|l|l|l|}
\hline \multicolumn{1}{|c|}{ Państwo } & \multicolumn{1}{|c|}{ Priorytet polityczny } & Sugerowane rozwiązanie & \multicolumn{1}{|c|}{ Karta przetargowa } \\
\hline Korea Północna & $\begin{array}{l}\text { Legitymizacja i gwarancje } \\
\text { przetrwania dla reżimu } \\
\text { politycznego; nawiązanie } \\
\text { stosunków dyplomatycz- } \\
\text { nych z USA i Japonią }\end{array}$ & $\begin{array}{l}\text { Etapowe pod warun- } \\
\text { kiem uzyskania gwaran- } \\
\text { cji i pomocy USA }\end{array}$ & $\begin{array}{l}\text { Likwidacja posiada- } \\
\text { nej broni atomowej, } \\
\text { chemicznej i biolo- } \\
\text { gicznej }\end{array}$ \\
\hline Stany Zjednoczone & $\begin{array}{l}\text { Nieodwołalna likwidacja } \\
\text { broni nuklearnej zagraża- } \\
\text { jącej bezpieczeństwu USA }\end{array}$ & $\begin{array}{l}\text { Całościowe pod warun- } \\
\text { kiem zlikwidowania bro- } \\
\text { ni atomowej w KRL-D }\end{array}$ & $\begin{array}{l}\text { Gwarancje dla prze- } \\
\text { trwania reżimu }\end{array}$ \\
\hline ChRL & $\begin{array}{l}\text { Zachowanie wpływów na } \\
\text { Półwyspie Koreańskim; } \\
\text { niedopuszczenie do wyści- } \\
\text { gu zbrojeń w Azji }\end{array}$ & $\begin{array}{l}\text { Mediacja oraz działanie } \\
\text { na rzecz gwarancji dla } \\
\text { reżimu KRL-D }\end{array}$ & Pomoc gospodarcza \\
\hline
\end{tabular}

Źródło: J. Bayer, J. Dziak, Korea \& Chiny. Strategia i polityka, Instytut Studiów Politycznych PAN, Warszawa 2006, s. 265.

W momencie, kiedy dochodziło do powolnego zbliżenia amerykańsko-koreańskiego, a KRL-D porzuciła rozmowy sześciostronne, strona chińska postanowiła ponownie użyć narzędzi ekonomicznych. Przedsiębiorstwa chińskie zapowiadały masowe inwestycje w otwieranych w Korei Północnej strefach ekonomicznych, których na początku 2010 r. powstało ponad 12. W październiku 2009 r., w czasie wizyty chińskiego premiera Wen Jiabao, Chiny zaoferowały 200 mln USD na rozwój technologii, edukacji, turystyki oraz budowy nowego mostu na Yalu. Taka polityka była wynikiem reakcji na bilateralne zbliżenie Pjongjangu i Waszyngtonu. W lutym $2010 \mathrm{r}$. zadeklarowano $10 \mathrm{mld}$ USD na inwestycje $\mathrm{w}$ infrastrukturę w KRL-D, a w marcu inwestycje w nabrzeże w koreańskim porcie Raji ${ }^{2}$. Mimo tego polityka Pekinu nie dała żądanych efektów, a po przejęciu władzy przez Kim Jong Una Korea ludowa kontynuowała próby z bronią balistyczną ${ }^{93}$.

${ }_{92}$ Liu Junbo, Diplomatic Breatkthrough in the Nuclear Dilemma, „China International Studies" 2010, no. 1, s. 108-110.

93 Despite Risks, China Stays at North Korea's Side to Keep the U.S. at Bay, http://www. nytimes.com/2012/12/14/world/asia/china-stays-beside-north-korea-a-buffer-against-the-us.html? $\mathrm{r}=1 \&$ [dostęp 15.12.2012]. 


\section{Wnioski}

Wobec wzrastającej roli Chin i problemów gospodarczych Stanów Zjednoczonych relacje dwustronne stały się podstawowymi w relacjach światowych. W okresie dekady Hu Jintao Chiny wykorzystały możliwe platformy rozmów z USA, jednocześnie budując własną pozycję i przewagę w dialogu z mocarstwem światowym. Tym samym próbowano, z jednej strony, ograniczać wpływy w Azji Wschodniej, z drugiej zaś tworzyć okoliczności, w których, przy braku multilateralnego forum angażującego obie strony, podstawowym elementem nowego ładu międzynarodowego stają się relacje bilateralne. Niemniej jednak budowa pozycji chińskiej w Azji Wschodniej została zakłócona przez obawy mniejszych państw, które z racji na rosnącą potęgę Chin poszukują wsparcia ze strony Waszyngtonu, mającego prowadzić do równoważenia wpływów Pekinu.

W ramach stosowanych narzędzi w polityce zagranicznej Chin ważne jest podkreślenie, że i z punktu widzenia politycznego, i gospodarczego Pekin prowadzi politykę równoważenia wpływów amerykańskich, zarówno w regionie Azji Wschodniej, jak i na scenie globalnej. W tym kontekście Waszyngton jest podstawowym punktem odniesienia $\mathrm{w}$ polityce chińskiej, opartej na realistycznym paradygmacie balance of power. Tym samym tworzona jest sytuacja, w której pozostali aktorzy w stosunkach międzynarodowych stanowią tło i prowadzą własną politykę, niejako w cieniu relacji bilateralnych chińsko-amerykańskich ${ }^{94}$.

Narzędzia stosowane przez Pekin, mimo iż przynosiły spodziewane rezultaty, w postaci ograniczania pozycji Stanów Zjednoczonych, to jednak w coraz większym stopniu eksponowały Chiny jako lidera państw rozwijających się. $\mathrm{W}$ aspekcie stosowania narzędzi ideologicznych w polityce chińskiej istnieje obawa wynikająca z doświadczeń przeszłości. W czasach „rewolucji kulturalnej” silna ideologizacja działań w polityce zagranicznej doprowadziła do izolacji państwa na arenie międzynarodowej, wewnętrznego chaosu i braku rozwoju gospodarczego. Mimo że wydarzenia w Chinach okresu 1966-1976 przykuwały uwagę opinii światowej, to jednak Pekin stracił realne wpływy w relacjach międzynarodowych. Innym elementem w promowaniu ,chińskiego modelu” jest przywiązanie do wskazanej przez Deng Xiaopinga zasady taoguang yanghui, która mówi o konieczności ukrywania własnych możliwości, niebrania odpowiedzialności, a także nieprzewodzenia sztandarowi socjalizmu. Wreszcie promowanie wartości ideologicznych mogłoby zachwiać pragmatyczną postawą Chin na arenie międzynarodowej, co w dalszej konsekwencji stawiałoby Pekin przed konfrontacją ideologiczną z Waszyngtonem.

W Chinach panuje powszechne przekonanie, iż nowa architektura relacji międzynarodowych uzależniona jest od osłabienia „hegemonii” dolara amery-

94 Kang Ruihua, Qu Qiuhong, Daguo de huangjing waijiao yu Zhongguo de duice [Dypomacja mocarstw w otoczeniu Chin i chińska polityka], „Xiandai Guoji Guanxi”1999, no. 4, s. 34-35. 
kańskiego, a co za tym idzie - włączenia chińskiej waluty do międzynarodowego systemu. Służą temu narzędzia gospodarcze, tj. handel zagraniczny czy inwestycje bezpośrednie, a także chińskie inwestycje w amerykańskie papiery dłużne. Niewątpliwie taka sytuacja umożliwiła firmom chińskim inwestycje w USA, a także większy dostęp do amerykańskich rynków kapitałowych dla firm chińskich. Mimo pozytywnej oceny polityki chińskiej w zakresie gospodarczym wobec Stanów Zjednoczonych, sytuacja w której Pekin de facto sponsoruje rząd amerykański, staje się poważnym wyzwaniem. W momencie, gdy Ameryka zaangażowana była w wojnę z terroryzmem, władze w Pekinie umiejętnie wygrywały sytuację dla wewnętrznej polityki wobec mniejszości ujgurskiej. Jednak w momencie redefinicji amerykańskiej polityki i skierowania się na obszar Pacyfiku, okazało się, że Pekin udziela kredytu na prowadzenie polityki wymierzonej we własne interesy w regionie Azji Wschodniej. Ameryka w dalszym ciągu pozostaje największym wyzwaniem chińskiej polityki zagranicznej. Stany Zjednoczone wciąż są przedstawiane jako państwo „kapitalistyczne”, mające na celu wyzysk państw rozwijających się i posiadające narzędzia ideologiczne, które w każdej chwili mogą zostać użyte. Dodatkowo, z punktu widzenia prowadzenia polityki zagranicznej, potencjalnym zagrożeniem jest napływ zachodnich teorii stosunków międzynarodowych, które mogą w ,niechiński” sposób przedstawiać politykę zagraniczną ${ }^{95}$. Amerykański zwrot do Azji z końca 2011 r. sprawił, że Chiny stały się „sponsorem” polityki, która w dalszym ciągu prowadzi do otaczania Chin. Owa frustracja, związana zarówno z amerykańską polityką, jak i konfliktami z innymi „Wzrastającymi” mocarstwami, jak stwierdza Zhao Suisheng, może mieć istotny wpływ na bardziej asertywne zachowanie Pekinu ${ }^{96}$.

Pytaniem, pozostającym nadal bez odpowiedzi, jest kwestia, na ile oba mocarstwa będą w stanie stworzyć efektywny system zarządzania globalnym wymiarem stosunków międzynarodowych. Czy proponowana m.in. przez Zbigniewa Brzezińskiego formuła G2, mimo iż oficjalnie odrzucona przez władze w Pekinie, może stanowić, oprócz G20, nowy wymiar stosunków międzynarodowych? W tej materii Chiny pozostają przy pasywnej postawie i jedynie reagują na działania Stanów Zjednoczonych. Polityka amerykańska opiera się zatem na tworzeniu sojuszy bilateralnych i wymuszaniu na Chinach bardziej koncyliacyjnej postawy w rozmowach na temat przyszłej konstrukcji relacji globalnych. Chiny z kolei nadal prowadzą politykę reakcyjną, umiejętnie wykorzystując narzędzia w polityce zagranicznej i dając sobie czas na zwiększanie potencjału i możliwości w kreowaniu regionalnego i globalnego systemu relacji międzynarodowych.

95 A.J. Nathan, A. Scobell, How China Sees America the Sum of Beijing's Fears, „Foreign Affairs", September/October 2012, http://www.foreignaffairs.com/articles/138009/andrew-j-nathan-and-andrew-scobell/how-china-sees-america?page=4 [dostęp 12.12.2012].

96 Zhao Suisheng, Hu Jintao's Foreign Policy Legacy, http://www.e-ir.info/2012/12/08/hu-jintaos-foreign-policy-legacy/ [dostęp 15.12.2012]. 